\title{
Floristic Composition, Diversity and Status of Threatened Medicinal Plants in Tropical Forests of Malyagiri Hill Ranges, Eastern Ghats, India
}

\author{
S. C. Sahu and N. K. Dhal \\ Environment and Sustainability Department, \\ Institute of Minerals and Materials Technology (formerly RRL), CSIR, \\ Bhubaneswar (Odisha), \\ India
}

\section{Introduction}

Tropical and subtropical forests harbour maximum diversity of plant species found on the earth (WCMC, 1992). These forests are rich in medicinal and economically important plants. Exploitation of these forests has resulted in rapid loss of tropical forests and it is recognized as one of the serious environmental and economic problems all over the world (Hare et al., 1997). A study on floristic composition and species diversity of threatened medicinal plants of tropical forests is ecologically significant besides its usefulness in forest management.

Malyagiri hill ranges belonging to Eastern Ghats of India lies between $21^{\circ} 23^{\prime} 30^{\prime \prime} \mathrm{N}$ latitude and 85016' 58" E longitude, located in the Pallahara Sub-division of Angul District in Odisha. The whole area is endowed with rising and falling hills interspersed with small plains and winding strips of valleys. There are as many as 4 perennial water-falls with dense forests in the northern part known as "Nagira". These provide a congenial niche for the luxuriant growth of marshy plants of various types. "Mankra" a tributary of Brahmani flows in the west of Pallahara which keeps the sub-division aside from National Highway 6. The Lord Siva temple at hill base of Khuluri reserve forest with a perennial water-fall increases the beauty of nature and is a popular tourist place..

The soils of Malyagiri are mainly red and form clays and clay-loams in the valleys (Patra \& Choudhury, 1989). The hill ranges experience an extreme climate comprising of 3 distinct seasons; summer, rainy and winter. It enjoys an average annual rainfall of $1421 \mathrm{~mm}$. The highest temperature of $43.9^{\circ} \mathrm{C}$ is recorded in May and it drops to $14.6^{\circ} \mathrm{C}$ in December.

Malyagiri hill range harbours floristically important tropical deciduous forest of Eastern Ghats, India. The wide range of topographic and climatic conditions favour luxurious growth of vegetation in this hill range (Patra \& Choudhury, 1989). Many of the plants have immense medicinal properties. Due to over-exploitation of medicinal plants, fuel wood collection, habitat destruction and grazing, plant diversity of Malyagiri hill range is declining at an alarming rate (Sahu et al., 2010). This may lead to extinction of many valuable species. However, barring a few floristic and ethnobotanical works (Brahmam \& 
Saxena, 1990; Patra \& Choudhury, 1989; Saxena \& Dutta, 1975; Saxena et al., 1991), no quantitative study analyzing the vegetation structure of the forest has been undertaken. Therefore, a detailed study was undertaken to analyze the diversity, distribution and population structure of tree species in these forests.

\section{Materials and methods}

\subsection{Field sampling and data analysis}

Vegetation analysis was carried out during March 2007 to December 2009 by laying 60 quadrants for each element of vegetation. For all trees $\geq 15 \mathrm{~cm}$ girth at breast height $(\mathrm{GBH})$ were sampled through $20 \times 20 \mathrm{~m}$ quadrants with sampling intensity of $0.001 \%$ based on random sampling methods in tropical dry deciduous forest stand of 2.4 ha area. Individuals with less than $15 \mathrm{~cm}$ GBH were considered as saplings. The shrubs were sampled through 5 x $5 \mathrm{~m}$ and herbs, climbers and saplings were sampled by laying $1 \times 1 \mathrm{~m}$ quadrants. Herbarium specimens were prepared and the species were identified with the help of regional flora (Gamble \& Fischer, 1915-1935; Saxena \& Brahmam, 1996). The specimens were deposited in the herbarium (RRL-B) at Institute of Minerals and Materials Technology, Bhubaneswar. The vegetation data were analyzed for 57 tree species. Abundance (A), Frequency (F), Relative frequency (RF), Density (D), Relative density (RD), Basal Area (BA), Relative Basal Area (RBA), Importance Value Index (IVI), Shannon -Wiener index (Shannon and Weaver, 1963) and Simpson's index (Simpson, 1949) were calculated using the quadrant data and following the methods of Misra (1968). IVI of each species was calculated by summing the RF, RD and RBA following the methods of Curtis (1959). Abundance to Frequency (A/F) ratio of each species was calculated to study the dispersion pattern. The range of values for determining dispersion pattern were: regular $(<0.025)$, random $(0.025-$ 0.05 ) and contiguous (> 0.05) (Curtis and Cottam, 1956). Population structure of tree species was analyzed across the five girth classes. The status and degree of threat to medicinal plants in their natural habitat has been indicated by classifying them according to Red Data Book categories, as defined by the IUCN (Maheswari, 1977; Melville, 1970-71).

Shannon and Weiner's Index (1963) was calculated as follows:

$$
H^{\prime}=-\Sigma p_{i} \log p_{i}
$$

Where, $\mathrm{p}_{\mathrm{i}}=\mathrm{n}_{\mathrm{i}} / \mathrm{N}$

$\mathrm{n}_{\mathrm{i}}=$ Importance value for species " $\mathrm{i}$ "

$N=$ Total of importance value

Concentration of dominance was calculated following Simpson (1949):

$$
\mathrm{Cd}=\Sigma \mathrm{p}^{2}
$$

Where $\mathrm{p}_{\mathrm{i}}$ is same as the Shannon- Wiener Index.

\section{Results and discussion}

The dominant forest type of Malyagiri hill range is tropical dry deciduous forest (Champion and Seth, 1968). A total of 1063 trees belonging to 57 species were recorded from 60 sample 
plots. The dominant tree species in descending order of IVI are Shorea robusta Gaertn.f. (44.67), Terminalia alata Heyne ex Roth. (31.98), Madhuca indica Gmel. (17.3), Anogeissus latifolia (Roxb. Ex DC.) Wall.ex Guill. \& Perr. (15.64), Diospyros melanoxylon Roxb. (13.41) (Table-1).

\begin{tabular}{|c|c|c|c|c|c|}
\hline Name of the species & F (\%) & D (ind. ha-1) & BA $\left(m^{2} . h^{-1}\right)$ & IVI & Distribution \\
\hline Aegle marmelos (L.) Corr. & 16.7 & 8.8 & 0.12 & 5.17 & $\mathrm{C}$ \\
\hline Albizia lebbeck (L.) Benth. & 3.3 & 0.8 & 0.04 & 0.93 & $\mathrm{C}$ \\
\hline Alstonia scholaris (L.) R.Br. & 3.3 & 0.8 & 0.01 & 0.73 & $\mathrm{C}$ \\
\hline $\begin{array}{l}\text { Anogeissus latifolia (Roxb. ex } \\
\text { DC.) Wall.ex Guill. \& Perr. }\end{array}$ & 50.0 & 12.5 & 0.01 & 15.64 & $\mathrm{Ra}$ \\
\hline Bauhinia purpurea L. & 1.7 & 0.8 & 0.01 & 0.45 & $C$ \\
\hline Bombax ceiba L. & 3.3 & 1.3 & 0.01 & 0.72 & $\mathrm{C}$ \\
\hline Bridelia retusa (L.) Spreng. & 1.7 & 0.3 & 0.01 & 0.26 & $\mathrm{C}$ \\
\hline Buchanania lanzan Spreng. & 38.3 & 24.5 & 0.34 & 8.15 & $\mathrm{C}$ \\
\hline Careya arborea Roxb. & 5.0 & 2.5 & 0.03 & 1.47 & $\mathrm{C}$ \\
\hline Casearia graveolens Dalz. & 18.3 & 10.8 & 0.11 & 5.74 & $\mathrm{C}$ \\
\hline Cassia fistula $\mathrm{L}$. & 11.7 & 3.3 & 0.04 & 2.63 & $\mathrm{C}$ \\
\hline Chloroxylon swietiana DC. & 15.0 & 6.5 & 0.07 & 4.01 & $\mathrm{C}$ \\
\hline $\begin{array}{l}\text { Cleistanthus collinus (Roxb.) } \\
\text { Benth.ex.Hook.f. }\end{array}$ & 26.7 & 15.8 & 0.12 & 8.13 & $\mathrm{C}$ \\
\hline Dalbergia paniculata Roxb. & 1.7 & 0.3 & 0.02 & 0.46 & $\mathrm{C}$ \\
\hline Dalbergia sisoo Roxb. & 1.7 & 0.3 & 0.01 & 0.35 & $\mathrm{C}$ \\
\hline $\begin{array}{l}\text { Diospyros malabarica (Desr.) } \\
\text { Kostel. }\end{array}$ & 20.0 & 14.0 & 0.49 & 6.24 & $\mathrm{C}$ \\
\hline Diospyros melanoxylon Roxb. & 36.7 & 19.0 & 0.56 & 13.41 & $\mathrm{Ra}$ \\
\hline Diospyros montana Roxb. & 8.3 & 4.5 & 0.16 & 3.36 & $\mathrm{C}$ \\
\hline Erythrina variegata $\mathrm{L}$. & 1.7 & 0.3 & 0.69 & 5.32 & $\mathrm{C}$ \\
\hline Ficus benghalensis L. & 1.7 & 0.3 & 0.01 & 0.26 & $\mathrm{C}$ \\
\hline $\begin{array}{l}\text { Ficus semicordata Buch.- } \\
\text { Ham.ex J.E.Sm. }\end{array}$ & 3.3 & 0.8 & 0.02 & 0.74 & $\mathrm{C}$ \\
\hline Ficus mollis. Vahl & 16.7 & 7.0 & 0.11 & 4.61 & C \\
\hline Gardenia latifolia Ait. & 8.3 & 5.8 & 0.13 & 3.38 & $\mathrm{C}$ \\
\hline Glochidion velutinum Wight & 3.3 & 1.3 & 0.04 & 1.02 & $\mathrm{C}$ \\
\hline Gmelina arborea Roxb. & 28.3 & 14.5 & 0.21 & 8.67 & $\mathrm{C}$ \\
\hline $\begin{array}{l}\text { Haldinia cordifolia (Roxb.) } \\
\text { Ridsd. }\end{array}$ & 1.66 & 0.8 & 0.05 & 0.8 & $\mathrm{C}$ \\
\hline Ixora pavetta Andr. & 10 & 5.0 & 0.03 & 2.67 & $\mathrm{C}$ \\
\hline Lagerstroemia parviflora Roxb. & 13.3 & 7.0 & 0.30 & 5.58 & $\mathrm{C}$ \\
\hline $\begin{array}{l}\text { Lannea coromandelica (Houtt.) } \\
\text { Merr. }\end{array}$ & 1.7 & 0.8 & 0.01 & 0.39 & $\mathrm{C}$ \\
\hline $\begin{array}{l}\text { Macaranga peltata (Roxb.) } \\
\text { Muell.-Arg. }\end{array}$ & 31.7 & 17.8 & 1.23 & 17.3 & $\mathrm{C}$ \\
\hline Madhuca indica Gmel. & 3.3 & 1.3 & 0.01 & 17.3 & $\mathrm{C}$ \\
\hline Mangifera indica L. & 15.0 & 9.5 & 1.00 & 11.54 & $\mathrm{C}$ \\
\hline
\end{tabular}




\begin{tabular}{|c|c|c|c|c|c|}
\hline Name of the species & $F(\%)$ & D (ind. ha-1) & $\mathrm{BA}\left(\mathrm{m}^{2} . \mathrm{ha}^{-1}\right)$ & IVI & Distribution \\
\hline Melastoma malabathricum L. & 35.0 & 18.3 & 0.26 & 10.75 & $\mathrm{Ra}$ \\
\hline $\begin{array}{l}\text { Mitragyna parvifolia (Roxb.) } \\
\text { Korth. }\end{array}$ & 13.3 & 6.3 & 0.10 & 3.94 & $\mathrm{C}$ \\
\hline Morinda pubescens Sm. & 1.7 & 0.3 & 0.01 & 0.27 & $\mathrm{C}$ \\
\hline Murraya paniculata (L.) Jack & 13.3 & 6.5 & 0.06 & 3.71 & $\mathrm{C}$ \\
\hline Nyctanthes arbor-tristis L. & 10.0 & 3.3 & 0.04 & 2.39 & $\mathrm{C}$ \\
\hline Phyllanthus emblica L. & 5.0 & 2.5 & 0.04 & 1.6 & $\mathrm{C}$ \\
\hline $\begin{array}{l}\text { Polyalthia cerasoides (Roxb.) } \\
\text { Bedd. }\end{array}$ & 8.3 & 4.5 & 0.04 & 2.42 & $\mathrm{C}$ \\
\hline $\begin{array}{l}\text { Protium serratum (Wall. ex } \\
\text { Colebr.) Engl. }\end{array}$ & 1.7 & 0.3 & 0.03 & 0.46 & $\mathrm{C}$ \\
\hline Pterocarpus marsupium Roxb. & 15.0 & 7.0 & 0.09 & 4.25 & C \\
\hline $\begin{array}{l}\text { Pterospermum acerifolium (L.) } \\
\text { Willd. }\end{array}$ & 13.3 & 5.3 & 0.09 & 3.63 & $\mathrm{C}$ \\
\hline $\begin{array}{l}\text { Pterospermum xylocarpum } \\
\text { (Gaertn.) Sant \& Wagh }\end{array}$ & 6.7 & 3.8 & 0.04 & 2 & $\mathrm{C}$ \\
\hline Randia malabarica Lam. & 1.7 & 0.3 & 0.01 & 0.26 & $\mathrm{C}$ \\
\hline $\begin{array}{l}\text { Schleichera oleosa (Lour.) } \\
\text { Oken }\end{array}$ & 10.0 & 10.8 & 0.32 & 6.17 & $\mathrm{C}$ \\
\hline Semecarpus anacardium L.f. & 3.3 & 1.3 & 0.02 & 0.86 & $\mathrm{C}$ \\
\hline Shorea robusta Gaertn.f. & 73.3 & 59.5 & 2.88 & 44.67 & $\mathrm{Ra}$ \\
\hline Strychnos potatorum L.f. & 11.7 & 6.5 & 0.23 & 4.74 & $\mathrm{C}$ \\
\hline Symplocos racemosa Roxb. & 11.7 & 8.3 & 0.05 & 3.84 & $\mathrm{C}$ \\
\hline Syzygium cumini (L.) Skeels & 13.3 & 6.3 & 0.21 & 4.74 & $\mathrm{C}$ \\
\hline $\begin{array}{l}\text { Terminalia alata Heyne ex } \\
\text { Roth. }\end{array}$ & 65.0 & 49.5 & 1.62 & 31.98 & $\mathrm{Ra}$ \\
\hline $\begin{array}{l}\text { Terminalia arjuna (Roxb.ex } \\
\text { DC.) Wight \& Arn. }\end{array}$ & 3.3 & 2.0 & 0.31 & 3.13 & $\mathrm{C}$ \\
\hline $\begin{array}{l}\text { Terminalia bellirica (Gaertn.) } \\
\text { Roxb. }\end{array}$ & 5.0 & 1.5 & 0.07 & 1.5 & C \\
\hline Terminalia chebula Retz. & 3.3 & 1.3 & 0.02 & 0.87 & $\mathrm{C}$ \\
\hline $\begin{array}{l}\text { Wendlandia tinctoria (Roxb.) } \\
\text { DC. }\end{array}$ & 23.3 & 12.0 & 0.16 & 7.05 & $\mathrm{C}$ \\
\hline Xylia xylocarpa (Roxb.) Taub. & 10.0 & 5.8 & 0.11 & 3.37 & $\mathrm{C}$ \\
\hline $\begin{array}{l}\text { Ziziphus xylocarpus (Retz.) } \\
\text { Willd. }\end{array}$ & 5.0 & 32.5 & 0.01 & 1 & C \\
\hline
\end{tabular}

Note: F- Frequency; D- Density; BA-Basal Area; IVI-Importance Value Index; Ra: Random; C: Contiguous

Table 1. Phytosociological characteristics of Tree species in Malyagiri hill range, Eastern Ghats

The luxuriant growth of herbs, shrubs and climbers increased the density of the forest vegetation. Among the herbs, Chromolaena odorata (L.) R.King \& H.Robins., Andrographis paniculata (Burm.f.) Wall.ex Nees, Elephantopus scaber L., Curculigo orchioides Gaertn. were 
most common species. Important shrub species were Combretum roxburghii Spreng., Holarrhena pubescence (Buch.-Ham.) Wall.ex G.Don, Woodfordia fruticosa (L.) Kurtz, Lantana camara L., Helicteres isora L. and Ixora pavetta Andr. The dominant climbers were Dioscorea bulbifera L., Smilax macrophylla Roxb., Ampelocissus latifolia (Roxb.) Planch. and Bauhinia vahlii Wight \& Arn.

However, Malyagiri hill range is severely affected by anthropogenic activities. Unsustainable collection of medicinal plants (Oroxylum indicum (L.) Vent. and Cycas cicinalis L.) for selling purposes by the local people of Pallahara Sub-division (Sahu et al., 2010) is prominent. Most of the local people depend upon the forests for their livelihood for which collection of leaf from Bauhinia vahlii Wight \& Arn. (Leaf tray), Phoenix sylvestris (L.) Roxb. (for brooms, mats etc.), Diospyros melanoxylon Roxb. (Bidi) and firewood collection are very common. These are the indications to the anthropogenic activities going on in and around Malyagiri hill ranges.

Out of 57 tree species, five species were randomly distributed and 52 species were contiguously distributed. The study reveals prevalent clumping nature of tree species in the tropical forest of Malyagiri hill ranges. Odum (1971) stated that contiguous distribution is the commonest pattern of plant distribution in nature. Kumar and Bhatt (2006) also reported that most species follow contiguous distribution pattern in foot-hills forests of Garhwal Himalaya and Rao et al. (1990) had similar findings for tree species of a subtropical forest of north-east India. The Shannon-Wiener index $\left(\mathrm{H}^{\prime}\right)$ was 3.38 and Simpson's index was 1.0. These values indicate that tropical deciduous forests are species diverse systems. The diversity value $\left(\mathrm{H}^{\prime}\right)$ of 3.38 falls within the range of 0.83-4.1 reported by earlier workers for Sal forest (Rasingam \& Parathasarathy, 2009; Shukla, 2009; Singh et al., 1985; Tripathi \& Singh, 2009; Visalakshi, 1995).

The mean tree density of the forest was $443 \mathrm{ha}^{-1}$. The mean stand density of the forest is well within the range of $276-905$ stems $^{-1}$ reported for trees $\geq 15 \mathrm{~cm} \mathrm{GBH}$ in other tropical forests (Bhadra et al., 2010; Nirmal Kumar et al., 2010; Sahu et al., 2007). The value obtained for basal area in the present study is comparable to the Indian tropical forests (Visalakshi, 1995).

Stem density and species richness consistently decreased with increasing girth class of tree species beyond 30-50 cm GBH class (Fig. 1). The highest GBH was in Ficus benghalensis (458 $\mathrm{cm})$ followed by Mangifera indica $(378 \mathrm{~cm})$, Shorea robusta $(230 \mathrm{~cm})$, Madhuca indica $(215 \mathrm{~cm})$ and Schleichera oleosa $(210 \mathrm{~cm})$. Girth class frequency showed reverse J-shaped population structure of trees, which is in conformity with other forest stands in Eastern Ghats such as Shervarayan hills (Kaduvul and Parthasarathy, 1999a) and Kalrayan hills (Kaduvul and Parthasarathy, 1999b).

The mean tree height was $10 \mathrm{~m}$ with a height range of 1 to $35 \mathrm{~m}$. Tree distribution by height class intervals shows that $39.1 \%$ of individuals were in the height class of 5-10 m, followed by $24.3 \%$ in the height class of $10-15 \mathrm{~m}$ and $20.4 \%$ in the height class of $0-5 \mathrm{~m}$ (Fig. 2). Only $5.73 \%$ of individuals were in the height class of $>20 \mathrm{~m}$. The tallest trees were Shorea robusta (35 m), Mangifera indica (33 m), Terminalia bellirica (32 m), Syzygium cumini (32 m), Diospyros malabarica (27).

The data on species/genus (S/G) ratio helps to compare the rate of species development because high ratio indicates recent diversification. Tropical areas have low species/genus ratio, indicating that the tropical species have emerged over a long period of time (Ricklefs 
and Miller, 2000). In the present study, all the study sites show lower S/G ratio in the tree layer (1.18), thus showing conformity with the findings of Ricklefs and Miller (2000).

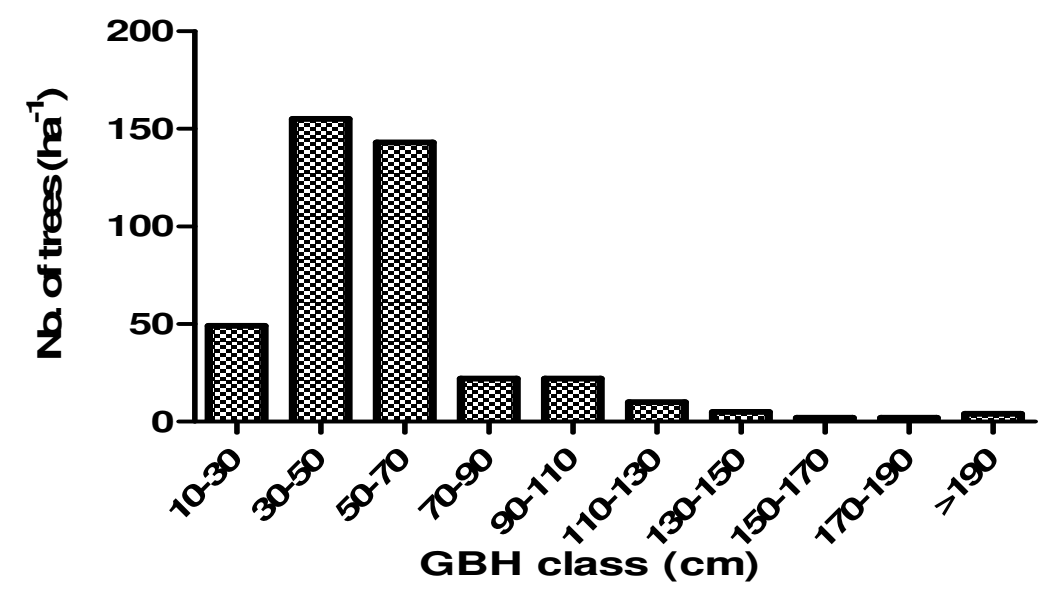

Fig. 1. Distribution of trees in different Girth classes in Malyagiri hill ranges, Eastern Ghats

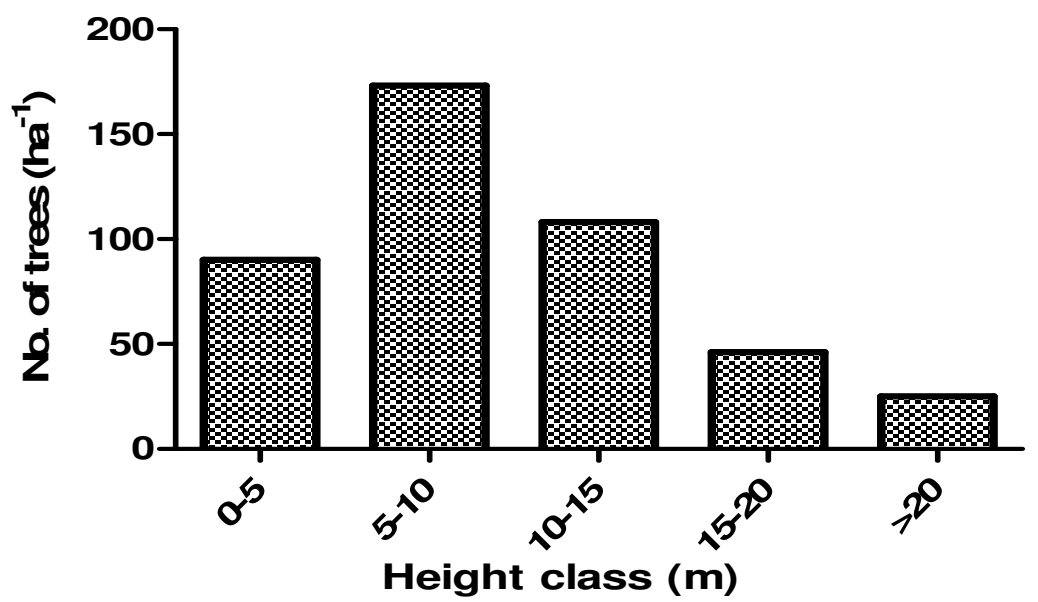

Fig. 2. Distribution of trees in different Height classes in Malyagiri hill ranges, Eastern Ghats

The invasive, exotic species were also found, which can be a serious threat to the forest ecosystem in the future. Important among them are Ageratum conyzoides L., Chromolaena odorata (L.) R. King \& H. Robins., Crotalaria pallida Ait., Hyptis suaveolens (L.) Poit., Lantana camara L., Mimosa pudica L., Parthenium hysterophorus L. and Triumfetta rhomboidea Jacq.

Girth class frequency showed J-shaped population structure of trees exhibited in the study sites are in conformity with many other forest stands in Eastern and Western Ghats such as Shervarayan hills (Kadavul and Parathasarthy, 1999a); Kalrayan hills (Kadavul and Parthasarathy, 1999b); Kakachi (Ganesh et al., 1996); Andaman Islands (Rasingam \& Parathasarathy, 2009). 


\section{Documentation of threatened medicinal plants}

Rapid destruction of forests causes severe damage to natural forest of the hill range, thus threatening the very survival of several indigenous medicinal plants. Recent news paper has highlighted the rate of medicinal plants (Oroxylum indicum (L.) Vent. and Cycas cicinalis L.) collection for selling purposes by the local people of Pallahara Sub-division in Malyagiri hill range (Sahu et al., 2010). Unsustainable collection of medicinal plants has placed them in threatened and vulnerable categories in Conservation Assessment and Management Plan (Ved et al., 2007) of Odisha. Table 2 highlights the 2 critically endangered, 6 endangered and 10 vulnerable species along with their botanical name, voucher specimen number, family, locality, local name, life form, distribution and IUCN status. So it is critical to conserve these medicinal plants locally if not globally. This may be planned through in-situ or ex-situ conservation methods, for preserving the biodiversity of the state of Odisha. In-situ conservation method should be implemented to conserve the medicinal plant resources in their natural habitat (National Park/Wildlife Sanctuary/Biosphere Reserve). Therefore, it is suggested that Malyagiri hills should be declared as a Wildlife Sanstuary in earlier possible. Threatened medicinal plants which will be extinct in near future should be conserved through ex-situ conservation (Botanical gardens, Arboreta or Seed banks).

\begin{tabular}{|l|l|l|l|l|l|l|}
\hline $\begin{array}{l}\text { Sl. } \\
\text { No. }\end{array}$ & $\begin{array}{l}\text { Botanical } \\
\text { name, } \\
\text { Voucher } \\
\text { specimen No. }\end{array}$ & Family, Locality & Local Name & Life form & Distribution & $\begin{array}{l}\text { IUCN } \\
\text { Status }\end{array}$ \\
\hline 1 & $\begin{array}{l}\text { Caesalpinia } \\
\text { digyna Rottl., } \\
8502\end{array}$ & $\begin{array}{l}\text { Caesalpiniaceae, } \\
\text { Allora }\end{array}$ & Gilo & Shrub & Peninsular India & Vulnerable \\
\hline 2 & $\begin{array}{l}\text { Celastrus } \\
\text { paniculata } \\
\text { Willd., } 9996\end{array}$ & $\begin{array}{l}\text { Celastraceae, } \\
\text { Kerjeng }\end{array}$ & Pengu & $\begin{array}{l}\text { Climbing } \\
\text { Shrub }\end{array}$ & Myanmar, Thailand & Vulnerable \\
\hline 3 & $\begin{array}{l}\text { Garcinia } \\
\text { xanthochymus } \\
\text { Hook.f., } 8572\end{array}$ & $\begin{array}{l}\text { Clusiaceae, } \\
\text { Panichua }\end{array}$ & Satyamba & Tree & $\begin{array}{l}\text { Eastern Himalayas, } \\
\text { Odisha, Myanmar, } \\
\text { Thailand }\end{array}$ & Vulnerable \\
\hline 4 & $\begin{array}{l}\text { Gardenia } \\
\text { gummifera } \\
\text { L.f., } 9759\end{array}$ & $\begin{array}{l}\text { Rubiaceae, } \\
\text { Kerjeng }\end{array}$ & Gurudu & Shrub & Peninsular India & Vulnerable \\
\hline 5 & $\begin{array}{l}\text { Gloriosa } \\
\text { superba } \text { L., } \\
\text { 11624 }\end{array}$ & $\begin{array}{l}\text { Liliaceae, } \\
\text { Pallahara }\end{array}$ & Nanangalia & $\begin{array}{l}\text { Climbing } \\
\text { herb }\end{array}$ & $\begin{array}{l}\text { Tropical India, S. } \\
\text { Africa, Malesia }\end{array}$ & Vulnerable \\
\hline 6 & $\begin{array}{l}\text { Litsea } \\
\text { glutinosa } \\
\text { Lour.) } \\
\text { Robins., } 8636\end{array}$ & $\begin{array}{l}\text { Lauraceae, } \\
\text { Khuludi }\end{array}$ & Ledhachhali & Tree & $\begin{array}{l}\text { India, Sri Lanka, } \\
\text { Malesia }\end{array}$ & Endangered \\
\hline 7 & $\begin{array}{l}\text { Mesua ferrea } \\
\text { L., } 12027\end{array}$ & $\begin{array}{l}\text { Clusiaceae, } \\
\text { Khuludi }\end{array}$ & Nageswar & Tree & $\begin{array}{l}\text { Eastern Himalayas, } \\
\text { Andaman \& Nicobar, } \\
\text { Tropical Asia }\end{array}$ & Endangered \\
\hline 8 & $\begin{array}{l}\text { Oroxylum } \\
\text { indicum (L.) } \\
\text { Vent., } 11811\end{array}$ & $\begin{array}{l}\text { Bignoniaceae, } \\
\text { Khamar }\end{array}$ & Phanphania & Tree & $\begin{array}{l}\text { India, Sri Lanka, } \\
\text { Indonesia }\end{array}$ & Endangered \\
\hline
\end{tabular}




\begin{tabular}{|c|c|c|c|c|c|c|}
\hline $\begin{array}{l}\text { Sl. } \\
\text { No. }\end{array}$ & \begin{tabular}{|l} 
Botanical \\
name, \\
Voucher \\
specimen No.
\end{tabular} & Family, Locality & Local Name & Life form & Distribution & $\begin{array}{l}\text { IUCN } \\
\text { Status }\end{array}$ \\
\hline 9 & \begin{tabular}{|l|} 
Paederia \\
foetida L., \\
8641 \\
\end{tabular} & $\begin{array}{l}\text { Rubiaceae, } \\
\text { Pallahara }\end{array}$ & Gandhali & $\begin{array}{l}\text { Climbing } \\
\text { Shrub }\end{array}$ & $\begin{array}{l}\text { North-East } \\
\text { India,Andaman \& } \\
\text { Nicobar, Thailand }\end{array}$ & Vulnerable \\
\hline 10 & $\begin{array}{l}\text { Piper longum } \\
\text { L., } 8438\end{array}$ & $\begin{array}{l}\text { Piperaceae, } \\
\text { Pallahara } \\
\end{array}$ & Pipali & Herb & $\begin{array}{l}\text { India, Sri Lanka, } \\
\text { Malay }\end{array}$ & Endangered \\
\hline 11 & $\begin{array}{l}\text { Polyalthia } \\
\text { cerasoides } \\
\text { (Roxb.) Bedd, } \\
8224\end{array}$ & $\begin{array}{l}\text { Annonaceae, } \\
\text { Allora }\end{array}$ & Ojhar & Tree & $\begin{array}{l}\text { Assam, } \\
\text { Odisha,Silhet, Pegu }\end{array}$ & Vulnerable \\
\hline 12 & $\begin{array}{l}\text { Pterocarpus } \\
\text { marsupium } \\
\text { Roxb., } 10129\end{array}$ & \begin{tabular}{|l} 
Fabaceae, \\
Kerjeng
\end{tabular} & Bija & Tree & $\begin{array}{l}\text { Andhra Pradesh, } \\
\text { Bihar, Kerala, } \\
\text { Karnataka, Sri Lanka }\end{array}$ & Endangered \\
\hline 13 & $\begin{array}{l}\text { Pueraria } \\
\text { tuberosa } \\
\text { (Willd.) DC., } \\
9659\end{array}$ & $\begin{array}{l}\text { Fabaceae, } \\
\text { Khuludi }\end{array}$ & $\begin{array}{l}\text { Bhuin } \\
\text { kakharu }\end{array}$ & Climber & India & Vulnerable \\
\hline 14 & $\begin{array}{l}\text { Rauvolfia } \\
\text { serpentina (L.) } \\
\text { Benth. Ex } \\
\text { Kurtz, } 8245 \\
\end{array}$ & $\begin{array}{l}\text { Apocynaceae, } \\
\text { Pallahara }\end{array}$ & Patalagarud & Undershrub & $\begin{array}{l}\text { Tropical Himalaya, } \\
\text { Deccan } \\
\text { Peninsula,Malaya, } \\
\text { Sri Lanka } \\
\end{array}$ & $\begin{array}{l}\text { Critically } \\
\text { Endangered }\end{array}$ \\
\hline 15 & $\begin{array}{l}\text { Scindapsus } \\
\text { officinalis } \\
\text { (Roxb.) } \\
\text { Schott, } 10139 \\
\end{array}$ & Araceae, Allora & Kelikadali & Climer & $\begin{array}{l}\text { Tropical } \\
\text { Himalaya,Sikkim, } \\
\text { Andaman,Myanmar }\end{array}$ & Vulnerable \\
\hline 16 & $\begin{array}{l}\text { Strychnos } \\
\text { potatorum L.f., } \\
8820\end{array}$ & $\begin{array}{l}\text { Strychnaceae, } \\
\text { Kerjeng }\end{array}$ & Nirmali & Tree & $\begin{array}{l}\text { West Bengal, Bihar, } \\
\text { Sri Lanka, Myanmar }\end{array}$ & Vulnerable \\
\hline 17 & $\begin{array}{l}\text { Symplocos } \\
\text { racemosa } \\
\text { Roxb., } 12025 \\
\end{array}$ & $\begin{array}{l}\text { Symplocaceae, } \\
\text { Khuludi }\end{array}$ & Lodha & Tree & $\begin{array}{l}\text { NE India, Tamil } \\
\text { Nadu, Karnataka, } \\
\text { Thailand }\end{array}$ & Endangered \\
\hline 18 & $\begin{array}{l}\text { Uraria picta } \\
\text { (Jacq.) } \\
\text { Desv.ex DC., } \\
10925\end{array}$ & $\begin{array}{l}\text { Fabaceae, } \\
\text { Khuludi }\end{array}$ & Ishwarjata & Undershrub & $\begin{array}{l}\text { Himalaya, Sri Lanka, } \\
\text { SE Asia }\end{array}$ & $\begin{array}{l}\text { Critically } \\
\text { Endangered }\end{array}$ \\
\hline
\end{tabular}

Table 2. List of Threatened Medicinal plants in Malyagiri hills, Odisha

\section{Conclusion}

Reverse J-shaped population structure of trees denotes an evolving or expanding population, which needs to be maintained. The unsustainable collection of medicinal plants such as the bark of Oroxylum indicum (L.) Vent. and whole plant of Gloriosa superba L. and Uraria picta (Jacq.) Desv.ex DC., need to be checked to maintain the favourable population structure. Study on floristic composition and diversity will be useful to the conservation researchers and scientists and also to the forest managers for effective management of the forest ecosystem. The present investigation highlights the presence of threatened medicinal 
plants which need immediate attention for conservation and propagation through in-situ, ex-situ or latest biotechnological approaches (Gene banks, DNA and Pollen storage etc.)
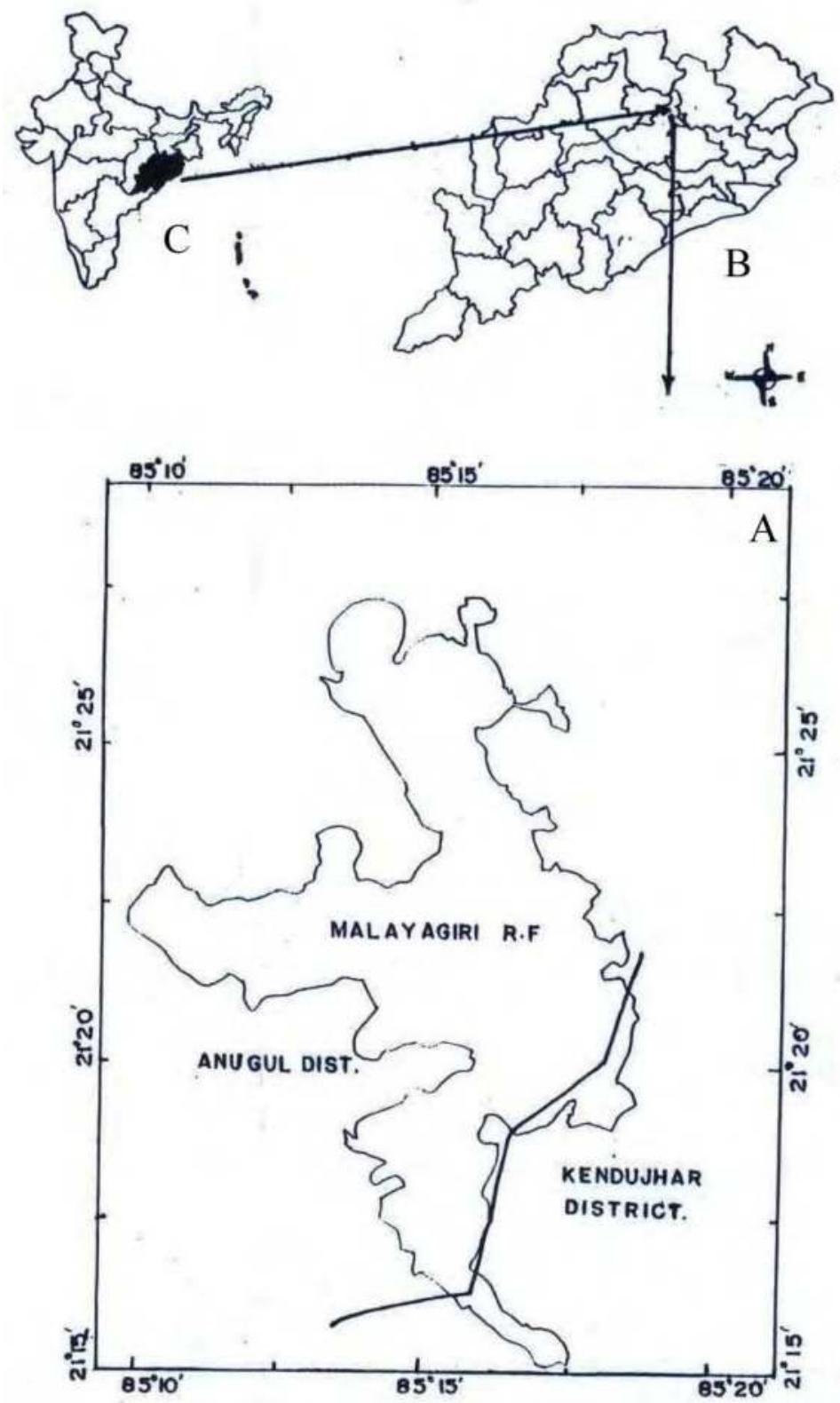

Fig. 3. Study area 
Some Threatened Medicinal Plants of Malyagiri hill ranges, Odisha, India

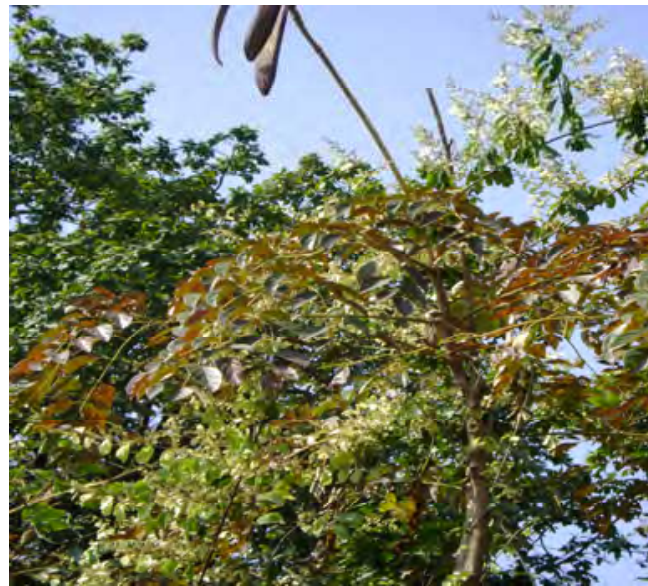

Oroxylum indicum (L.) Vent.

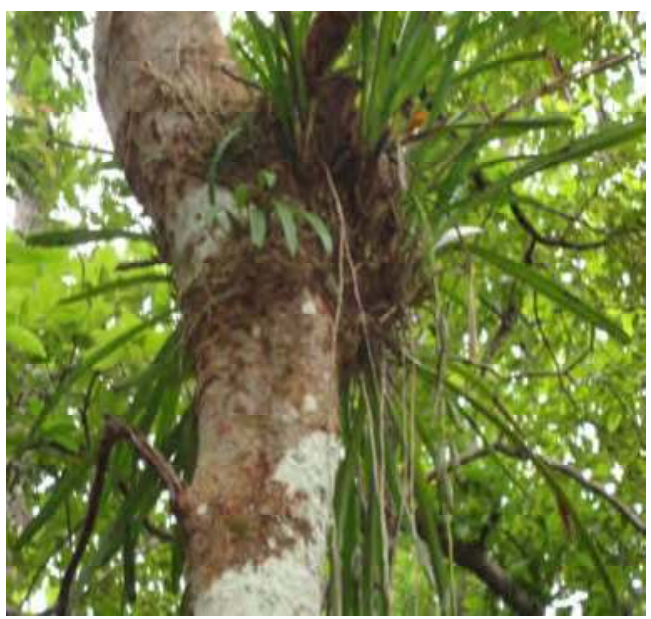

Cymbidium aloifolium (L.) Sw.

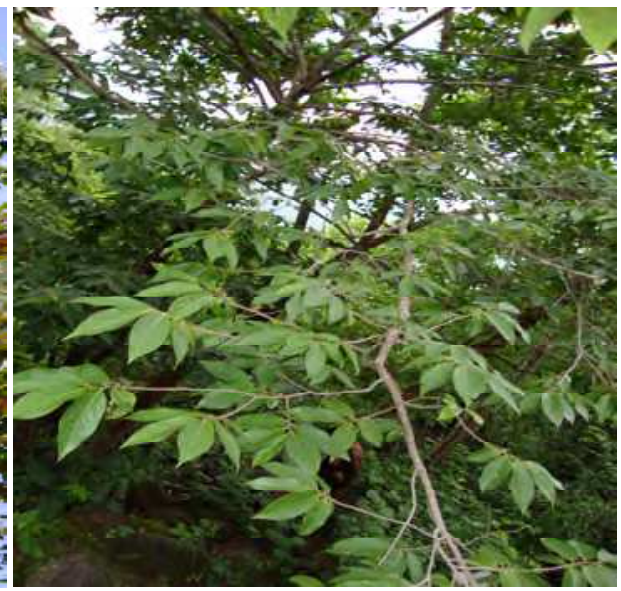

Polyalthia cerasoides (Roxb.) Bedd

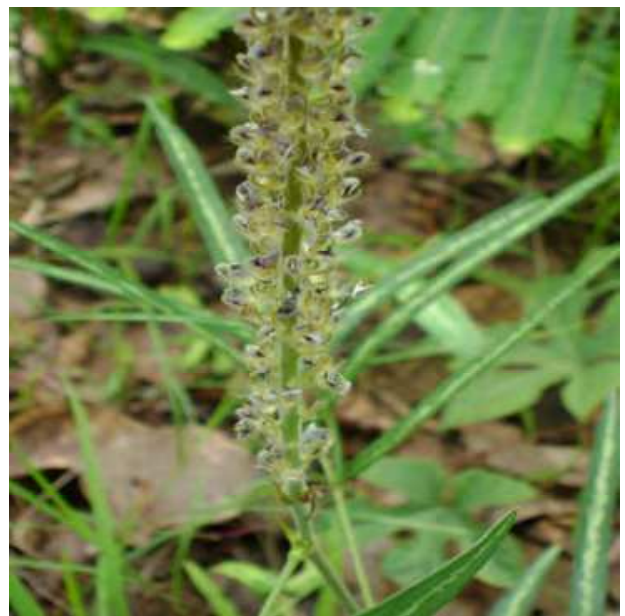

Uraria picta (Jacq.) Desv.ex DC.

\section{Acknowledgement}

The authors are sincerely thankful to the Director, IMMT, CSIR, Bhubaneswar, for providing necessary laboratory facilities. The help received from the local people involved during the survey is duly acknowledged. The first author is thankful to the Council of Scientific and Industrial Research, New Delhi, for the award of Senior Research Fellowship. 


\section{References}

Bhadra, A.K., Dhal, N.K., Rout, N.C. \& Reddy, V.R. (2010). Phytosociology of the tree community of Gandhamardan hill ranges. The Indian Forester, 136, 610-620.

Brahmam, M. \& Saxena, H.O. (1990). Ethnobotany of Gandhamardan hills. Some noteworthy folk medicinal uses. Ethnobotany, 2, 71-79.

Champion, H.G. \& Seth, S.K.. (1968). Revised Survey of Forest Types of India, New Delhi. Govt. of India.

Curtis, J.T. (1959). The Vegetation of Wisconsin, An Ordination of Plant Communities. University Wisconsin Press, Madison, Wisconsin.

Curtis, J.T. \& Cotton, G. (1956). Plant Ecology Workbook, Laboratory Field Manual. Burgess publishing, Minnesota. pp.193.

Gamble, J.S. \& Fischer, C.E.C. (1915-1935). Flora of Presidency of Madras. Vols 1-3. Adlard and Son Ltd, London.

Ganesh, T., Ganesan, R., Soubadradevy, M., Davidar, P. \& Bawa, K. S. (1996). Assessment of plant biodiversity at a mid-elevation evergreen forest of Kalakad-Mudanthurai Tiger reserve, Western Ghats, India. Current Science, 71, 379-92.Hare, M.A., Lantagne, D.O., Murphy, P.G. \& Chero, H. (1997). Structure and tree species composition in a subtropical dry forest in the Dominican Republic: Comparision with a dry forest in Puerto Rico. Tropical Ecology, 38, 1-17.

Kadavul, K. \& Parthasarathy, N. (1999a). Plant biodiversity and conservation of tropical semi-evergreen forest in the Shervarayan hills of Eastern Ghats, India. Biodiversity Conservation, 8, 421-439.

Kadavul, K. \& Parthasarathy, N. (1999b). Structure and composition of woody species in tropical semi-evergreen forest of Kalayan hills, Eastern Ghats, India. Tropical Ecology 40, 247-260.

Kumar, Munesh \& V.P. Bhatt. 2006. Plant biodiversity and conservation of forests in foot hills of Garhwal Himalaya. Journal of Ecology and Application, 11, 43-59.

Maheswari, J.K. (1977). Conservation of Rare plants- Indian scene vis world scene. Bulletin of Botanical Survey of India, 19, 167-173.

Melville, R. (1970-71). Red Data Book. Vol. 5- Angiospermae. International Union for Conservation of Nature and Natural resources, Marges.

Mishra, R. (1968). Ecology Work Book. Oxford and IBH Publications, Co. New Delhi.

Nirmal Kumar, J.I., Kumar, Rita N., Bhoi, Rohit Kumar., \& Sajish, P.R. (2010). Tree species diversity and soil nutrient status in three sites of tropical dry deciduous forest of western India. Tropical Ecology, 51, 273-279.

Odum, E.P. (1971). Fundamentals of Ecology. 3rd edn. W.B. Saunders Co., Philadelphia. USA.

Patra, B.C. \& B.P. Choudhury. (1989). Forest cover of Malyagiri hills in the state of Orissa. Journal of Economic and Taxonomic Botany, 13, 315-319.

Rao, P., Barik, S.K., Pandey, H.N., \& Tripathi, R.S. (1990). Community composition and tree population structure in a subtropical broad-leaved forest along a disturbance gradient. Vegetatio, 88, 151-162.

Rasingam, L. \& Parathasarathy, N. (2009). Tree species diversity and population structure across major forest formations and disturbance categories in Little Andaman Island, India. Tropical Ecology, 50, 89-102.

Ricklefs, R.E. \& Miller, G.L. (2000). Ecology. - W.H. Freeman \& Company, New York. 
Sahu, S.C., Dhal, N.K., Reddy, C.S., Pattanaik, C., \& Brahmam, M. (2007). Phytosociological study of tropical dry deciduous forest of Boudh district, Orissa, India. Research Journal of Forestry, 1, 66-72.

Sahu, S.C., Dhal, N.K. \& Mohanty, R.C. (2010). Commercialization of a few wild medicinal plants from Deogarh district, Orissa, India. e-planet, 8, 14-16.

Saxena, H.O. \& Dutta, P.K. (1975). Studies on ethnobotany of Orissa. Bulletin of Botanical Survey of India, 17, 124-131.

Saxena, H.O., Brahmam, M., \& Dutta, P.K. (1991). Ethnobotanical studies in of Orissa. Pp.123135. In S.K. Jain (ed.) Contribution to Ethnobotany of India. Scientific Publishers, Jodhpur, India.

Saxena, H.O. \& Brahmam, M. (1996). The Flora of Orissa. Vols I-IV. Orissa Forest Development Corporation Ltd, Bhuabneswar, India.

Shannon, C.E. \& Weaver, W. (1963). The Mathematical Theory of Communication. University of Illinois Press, Urbana.

Shukla, R.P. (2009). Patterns of plant species diversity across Terai landscape in northeastern Uttar Pradesh, India. Tropical Ecology, 50, 111-123.

Simpson, E.H. (1949). Measurement of diversity. Nature, 163, 688.

Singh, J.S., Singh, S.P., Saxena, A.K., \& Rawat, Y.S. (1985). The forest vegetation of Silent Valley, in India. P. 25-52. In: A.C. Chadwick and S.L. Sutton (eds.). Tropical Rain Forest: The Leeds Symposium. Leeds Philosophical and Literary Society, Leeds, U.K.

Tripathi, K.P., \& Singh, B. (2009). Species diversity and vegetation structure across various strata in natural and plantation forests in Katerniaghat Wildlife Sanctuary, North India. Tropical Ecology, 50, 191-200.

Ved D. K., Kinhal G. A., Ravikumar K., Vijayasankar R., Sumathi R., Mahapatra A.K. and Panda P.C. (2007). CAMP Report: Conservation assessment and management prioritization for medicinal plants of Orissa, India. Foundation for Revitalisation of Local Health Traditions (FRLHT), Bangalore, India.

Visalakshi, N. (1995). Vegetation analysis of two tropical dry evergreen forests in southern India. Tropical Ecology, 36, 117-127.

World Conservation Monitoring Centre. (1992). Global biodiversity: Status of the Earths Living Resources. Chapman and Hall. London. 


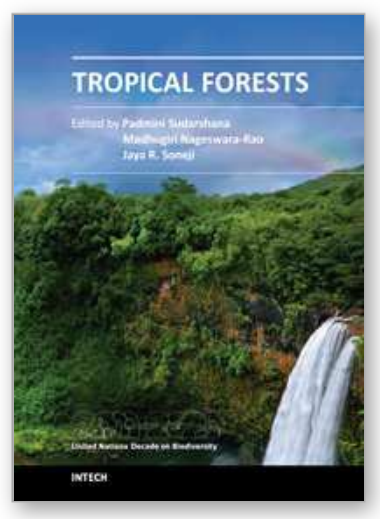

\author{
Tropical Forests \\ Edited by Dr. Padmini Sudarshana
}

ISBN 978-953-51-0255-7

Hard cover, 388 pages

Publisher InTech

Published online 14, March, 2012

Published in print edition March, 2012

The astounding richness and biodiversity of tropical forests is rapidly dwindling. This has severely altered the vital biogeochemical cycles of carbon, phosphorus, nitrogen etc. and has led to the change in global climate and pristine natural ecosystems. In this elegant book, we have defined "Tropical Forests" broadly, into five different themes: (1) tropical forest structure, synergy, synthesis, (2) tropical forest fragmentation, (3) impact of anthropogenic pressure, (4) Geographic Information System and remote sensing, and (5) tropical forest protection and process. The cutting-edge synthesis, detailed current reviews, several original data-rich case studies, recent experiments/experiences from leading scientists across the world are presented as unique chapters. Though, the chapters differ noticeably in the geographic focus, diverse ecosystems, time and approach, they share these five important themes and help in understanding, educating, and creating awareness on the role of "Tropical Forests" for the very survival of mankind, climate change, and the diversity of biota across the globe. This book will be of great use to the students, scientists, ecologists, population and conservation biologists, and forest managers across the globe.

\title{
How to reference
}

In order to correctly reference this scholarly work, feel free to copy and paste the following:

S. C. Sahu and N. K. Dhal (2012). Floristic Composition, Diversity and Status of Threatened Medicinal Plants in Tropical Forests of Malyagiri Hill Ranges, Eastern Ghats, India, Tropical Forests, Dr. Padmini Sudarshana (Ed.), ISBN: 978-953-51-0255-7, InTech, Available from: http://www.intechopen.com/books/tropicalforests/floristic-composition-diversity-and-status-of-threatened-medicinal-plants-in-tropical-forests-of-mal

\section{INTECH}

open science | open minds

\section{InTech Europe}

University Campus STeP Ri

Slavka Krautzeka 83/A

51000 Rijeka, Croatia

Phone: +385 (51) 770447

Fax: +385 (51) 686166

www.intechopen.com

\section{InTech China}

Unit 405, Office Block, Hotel Equatorial Shanghai

No.65, Yan An Road (West), Shanghai, 200040, China 中国上海市延安西路65号上海国际贵都大饭店办公楼 405 单元

Phone: +86-21-62489820

Fax: +86-21-62489821 
(C) 2012 The Author(s). Licensee IntechOpen. This is an open access article distributed under the terms of the Creative Commons Attribution 3.0 License, which permits unrestricted use, distribution, and reproduction in any medium, provided the original work is properly cited. 